\title{
FUCOIDAN FROM BROWN SEAWEED AND ITS BIOACTIVITY
}

\section{Fukoidan dari Rumput Laut Coklat dan Bioaktifitasnya}

\author{
Ellya Sinurat ${ }^{1)^{*}}$ and Endar Marraskuranto ${ }^{1)}$
}

\begin{abstract}
Research and Development Center for Marine and Fisheries Product Processing and Biotechnology, Ministry of Marine and Fisheries, KS. Tubun Petamburan VI, Jakarta Pusat 10260

*Corresponding author: ellya_sinurat@yahoo.com.
\end{abstract}

\begin{abstract}
Fucoidan is a polysaccharide which substantially consists of L-fucosa and ester sulphate group and is mainly contained in brown seaweed. For the past ten years, bioactivity studies of fucoidan has been conducted. Recently, fucoidan has been examined for its application in drugs. In a couple of years, fucoidan structure was succesfully identified and its bioactivity was revealed. Fucoidan exhibits various bioactivities such as anticoagulant, antioxidant, anticomplementary, anti-inflamation, gastric protector, and blood lipid level control. This review gives some brief progress in isolation and bioactivity study of fucoidan from brown seaweeds.
\end{abstract}

Key words: fucoidan, brown seaweed, bioactivity, L-fucose

\section{ABSTRAK}

Fukoidan adalah senyawa polisakarida yang secara substansional terdiri atas L-fukosa dan golongan ester sulfat, terutama terdapat pada rumput laut coklat. Dalam jangka waktu sepuluh tahun terakhir, bioaktivitas dari fukoidan telah banyak diteliti. Bahkan belakangan ini telah diteliti aplikasi fukoidan untuk obat. Dalam beberapa tahun terakhir, struktur fukoidan telah berhasil diidentifikasi dan bioaktivitasnya berhasil diketahui. Fukoidan mempunyai banyak bioaktifitas antara lain sebagai antikoagulan, antioksidan, antikomplementari, anti pembengkakan, pelindung lambung, dan pengatur kadar lipid darah. Review ini memberikan ringkasan beberapa kemajuan penelitian isolasi dan bioaktivitas fukoidan dari beberapa jenis rumput laut coklat penghasil fukoidan.

Kata kunci: fukoidan, rumput laut coklat, bioaktivitas, L-fukosa

\section{INTRODUCTION}

Fucoidan is a polysaccharides containing substantial percentage of L-fucose and sulphate ester group which is extracted from brown seaweed and some marine invertebrates (e.g. sea urchin and sea cucumber) (O'Neill, 1954; Patankar, 1993; Duarate, 2001). Polysaccharide, the name is fucoidan, initially come up when it was isolated from brown seaweed by Kylin in 1913. The name of fucoidan was established by IUPAC as fucan, fucosan, or sulphate fucan.

In the last decade, fucoidan was isolated from some different species and investigated widely for biological activity, e.g. anticoagulant, antioxidant, anticomplementary properties, antiinflamation, gastroprotector, reducing blood sugar, and antithrombosis. Compared to other sulphate polysaccharides, fucoidan is the most widely distributed and relatively cheap. Recently, fucoidan is also being use as drug and functional food. This paper is a review paper on the recent isolation research of fucoidan and its bioactivity.
Potential of brown seaweed as a fucoidan source has been widely researched, e.g. seaweed Fucus serratus in Murmansk region (Bilan et al., 2004); Undaria pinnatifida, Sporophyll from Korean (Kim et al., 2007); Sargassum polycystum and Sargassum oligocystum from Vietnam (Minh et al., 2005). In Indonesia, there are also several types of brown seaweed which potentially produce fucoidan. One type of brown seaweed species producing fucoidan that has been examined is Sargassum crassifolium (Sinurat et al., 2011). This type of seaweed was obtained from Binuangeun waters, Banten, West Java.

\section{FUCOIDAN STRUCTURE AND BIOLOGICAL ACTIVITY}

\section{Structure of Fucoidan}

Fucoidan was initially isolated by Kylin (1913) in Janet (2011), the structure from other brown seaweed species was also investigated. Fucoidan isolated from Fucus vesiculosus has a simple chemical 
composition especially consist of fucose and sulphate group, but actually fucoidan has a complex composition. Beside fucose and sulphate group, it also contains other monosaccharide group (e.g. mannose, galactose, glucose, xylose) and uronic acid, even acetyl and protein group. Variations of fucoidan structure depend on source, species of brown seaweed. Its backbone structure was successfully elucidated containing fucose and sulphate group ( $\mathrm{Li}$ Lu et al., 2008).

Recently, fucoidan extracted from Fucus vesiculosus is available commercially in the market. The compositions are fucose $44.1 \%$, sulphate $26.3 \%$, and ash $31.1 \%$, small amount of aminoglucose; its conformation is $\alpha-\mathrm{D}$ about $-123^{\circ}$ (Black et al., 1952; Nishino et al., 1992).

Based on methylation and alkali treatment, Conchie and O'Neill revealed that its backbone transformed into 1,2- $\alpha$ fucose and most of sulphate group was binded to C-4 on fucose unit (Li Rui et al., 2008). Anno et al. (1966) isolated L-fucose 4-sulphate from the same species and its infrared spectrum

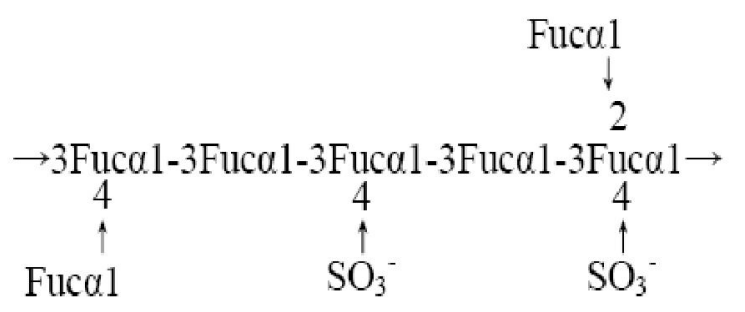

Figure 1. Structure model of fucoidan according to Patankar et al. (1993)

showed that sulphate group was substituted on atom axial C-4 from L-fucopyranose.

Structure model of fucoidan extracted from Fucus vesiculosus and proposed by Conchie had been accepted only after 40 years (Conchie, 1950). In 1993, GC/MS data on fucoidan methylation conducted by Patankar et al. (1993) rebuilt the structure model where its backbone was fucose polymer bonded through $\alpha-(1 \rightarrow 3)$ with sulphate group substituted on $\mathrm{C}-4$ in several fucose residues; fucose also bonded on the polymer forming a branch, e.g. one fucose for every 2-3 fucose residues on the backbone. Patankar et al. (1993) explained why his proposed structure is different from Conchie's. First, the preparation method: Conchie extracted fucoidan using hot water while Patankar using acid which become the standard method for extraction of commercial fucoidan for a couple of years; secondly, the methylation methods: Conchie analyzed his methylation products using chemical and chromatography method while Patankar using GC-EIMS (Anno et al., 1996).
Bilan et al. (2006) reported that fucoidan extracted from brown seaweed Fucus evanescens, Fucus distichus and Fucus serratus contained fucose, sulphate, and acetate. Fucoidan from F. evanescens had linier backbone containing $\alpha$-L-fucopyranose 2sulphate residue which is connected to 3 - and 4 - bond position of: $(1 \rightarrow 3)-\alpha-L-F u c p\left(2 \mathrm{SO}_{3}^{-}\right)-(1 \rightarrow 4)-\alpha-L-$ Fucp $\left(2 \mathrm{SO}_{3}^{-}\right)-(1 \rightarrow 4)$, alternately, where the added sulphate group is located in position 4 at the fucose residue that connected to 3 - and 4- position, while the remaining hydroxyl group is acetylated randomly. Fucoidan from $F$. distichus was arranged in alternating disaccharide unit of: (1 $\rightarrow 3)-\alpha-L-F u c p-(2,4-d i-S O 3-)-$ $(1 \rightarrow 4)-\alpha-L-F u c p-(2 S O 3)-(1 \rightarrow 3)$. This regular structure might be covered in small amount of randomly acetyl and sulphate unit in this several alternating disaccharide unit. Fucoidan from $F$. serratus has a branching structure, its main backbone is $(1 \rightarrow 3)-\alpha-L-$ Fucp-(1 $\rightarrow 4)-\alpha-L-F u c p-(1 \rightarrow 3)$, approximately half of its 3 -substituted binded residue on C-4 by $\alpha$-L-Fucp$(1 \rightarrow 4)$ - $\alpha$-L-Fucp-(1 $\rightarrow 3)-\alpha$-L-Fucp-( $1 \rightarrow$ trifucosyde) unit. Most of sulphate group occupy C-2 and occasionally C-4, eventhough diglycosilic unit is on position 3,4 and some terminal fucose residue might not has sulphate group. Acetate group occupies C-4 position through 3-fucose bond and C-3 through 4-fucose bond by $7: 3$ ratio. Fucoidan also contain xylose and galactose in small portion. Fucan from Stoechospermum marginatum has residue backbone of $\alpha$-L-fucopyranosil bound $(1 \rightarrow 4)$ - and $(1 \rightarrow 3)$ - which is substituted at position $\mathrm{C}-2$ and $\mathrm{C}-3$, and most of these residues sulphate fucosyl on C-2 and / or C-4.

The bulk structure of fucoidan can be investigated using various electron microscope techniques. Sulphate fucan from Padina gymnospora forms a highly regular structure and exhibits particles in polygonal shape with polycrystal structure pattern. In fact, these particles are consisted of sulphate fucan molecule since these particles are recognised from specific lectin as $\alpha$-L-fucosyl residue. X-ray microanalysis revealed that $S$ is major element according with sulphate group (Silva et al., 2005).

Chemical composition of fucoidan from Fucus vesiculosus is relatively more simple than commonly fucoidan which has complex composition. In 1962, Schweiger isolated polysaccharide from Macrocytis pyrifera resulting fucose and galactose ratio of 18:1, and stated for the first time that fucoidan was not pure sulphate fucan but a heteropolymer of fucose, galactose, and small amount of xylose ( $\mathrm{Li}$ et al., 2008). Furthermore, the other sugars such as mannosa, glucose, xylose, and glucuronic acid were also found in fucoidan from different species of brown seaweed (Table 1) where their existence made them hard to analyze the structure.

The characteristic of fucopyranose $1 \rightarrow 3$ bond structure appeared in fucoidan from Ecklonia kurome 
and Chorda filum. Fucoidan fraction isolated from $E$. kurome has a branching structure, its main backbone structure is $(1 \rightarrow 3)$-L-fucosyl and sulphate group which most are bonded to $\mathrm{C}-4$. Fucoidan isolated from Chorda filum comprises of poly- $\alpha-(1 \rightarrow 3)$ - fucopyranoside backbone with highly branched structure and most of them are $\alpha-(1 \rightarrow 2)$-fucopyranoside single unit. Some of fucopyranose residue contain sulphate on $\mathrm{O}-4$ position (most) and O-2. Some of $\alpha$-(1 $1 \rightarrow 3)$-fucose residue are displayed in NMR as acetylated-2-O.

\section{Biological Activity of Fucoidan}

\section{Anticoagulant}

Fucoidan has a very broad biological activities, however the most widely studied activity is its potential as anticoagulant. Nishino et al., (1991) conducted anticoagulant activity assay using fucoidan isolated from 9 species of brown seaweed, the parameter are activated partial thromboplastin time (APTT), thromboplastin time (TT), and Xa anti factor activity compared to heparin value (167 unit/mg). All fucoidans showed TT (0-35 unit/mg) and APTT (12-38 unit/mg) activity, while the Xa anti factor activity was not good for several fucoidans. Some of brown seaweed species which were being tested are: E. kurome which showed the highest activity APTT of 38 unit/mg and TT of 35 unit/mg. Hizikia fusiforme with APTT of $25 \mathrm{unit} / \mathrm{mg}$ and TT of 22 unit/mg. Anti-thrombin activity of F-4 fraction of fucoidan from Laminaria angustata var. longissima was $200 \mathrm{unit} / \mathrm{mg}$ compared to heparin (140 unit/mg).

Cumashi et al. (2007) conducted research on anticoagulant properties on fucoidan isolated from 9 brown seaweeds. All extracted fucoidan except Cladosiphon okamuranus, contained a lot of $2-\mathrm{O}-\alpha-$ D-glucuronopyranosil branches poli- $\alpha$-fucopyranoside

Table 1. Chemical composition of different brown seaweed species

\begin{tabular}{|c|c|}
\hline Brown seaweed species & Chemical composition \\
\hline F. vesiculosus & fucose, sulphate \\
\hline F. evanescens & fucose/sulphate/acetate $(1 / 1.23 / 0.36)$ \\
\hline F. distichus & fucose/sulphate/acetate $(1 / 1.21 / 0.08)$ \\
\hline F. serratus L. & fucose/sulphate/acetate $(1 / 1 / 0.1)$ \\
\hline Lessonia vadosa & fucose/sulphate (1/1.12) \\
\hline Macrocytis pyrifera & fucose/galactose (18/1), sulphate \\
\hline Pelvetia wrightii & fucose/galactose (10/1), sulphate \\
\hline Undaria pinnatifida (Mekabu) & fucose/galactose (1/1.1), sulphate \\
\hline Ascophyllum nodosum & $\begin{array}{l}\text { fucose }(49 \%), \text { xylose }(10 \%), \operatorname{GlcA}(11 \%), \\
\text { sulphate }\end{array}$ \\
\hline Himanthalia lorea and Bifurcaria bifurcate & fucose, xylose, GlcA, sulphate \\
\hline Padina pavonia & $\begin{array}{l}\text { fucose, xylose, mannosa, glucose, } \\
\text { galactose, sulphate }\end{array}$ \\
\hline Laminaria angustata & fucose/galactose/sulphate (9/1/9) \\
\hline Ecklonia kurome & $\begin{array}{l}\text { fucose, galactose, mannosa, xylose, GlcA, } \\
\text { sulphate }\end{array}$ \\
\hline Sargassum stenophyllum & $\begin{array}{l}\text { fucose, galactose, mannosa, GlcA, glucose, } \\
\text { xylose, sulphate }\end{array}$ \\
\hline Adenocytis utricularis & fucose, galactose, mannosa, sulphate \\
\hline Hizikia fusiforme & $\begin{array}{l}\text { fucose, galactose, mannosa, xylose, GlcA, } \\
\text { sulphate }\end{array}$ \\
\hline Dictyota menstrualis & $\begin{array}{l}\text { fucose/xylose/uronic acid/galactose/sulphate } \\
(1 / 0.8 / 0.7 / 0.8 / 0.4) \text { dan }(1 / 0.3 / 0.4 / 1.5 / 1.3)\end{array}$ \\
\hline Spatoglossum schroederi & fucose/xylose/galactose/sulphate (1/0.5/2/2) \\
\hline
\end{tabular}

Source: Li lu, 2008. 
linear chain which was attached through $(1 \rightarrow 3)$. They showed anticoagulant activity that measured as APTT, whereas only fucoidans from $L$. saccharina, $L$. digitata, F. serratus, F. distichus, and F. evanescens showed significant antithrombin activity on platelet aggregation test.

Many research showed that anticoagulant activity of fucoidan may be related to the sulphate content and position, molecular weight, and sugar composition. High sulphate content often shows high anticoagulant activity of fucoidan (Ecklonia kurome \& Hizikia fusiforme). However, anticoagulant activity increased while antithrombin activity decreased along with theincrement of sulphate content in fucan ( $\mathrm{Li}$ et al., 2008). Fucoidan which was excessively sulphate and made by reacting natural fucoidan with sulphate also supported this fact. Nishino et al., (1991) made three types of excessively sulphate fucan with different type of sulphate content (ratio of sulphate/sugar, 1.38 -1.98) by means of sulphation reaction of sulphate fucan (sulphate/sugar, 1.28) isolated from E. kurome. Anticoagulant activity of the fucan for APTT and TT respectively were increased $110-119 \%$ and $108-140 \%$ from the initial activity. Anticoagulant activity for APTT values (173 unit/mg) for excessively sulphate fucan (ratio of sulphate/sugar, 1.98) was higher than standard heparin (167 unit/mg). Antithrombin activity of cofactor II-mediated heparin of excessively sulphate fucan also increased significantly with the addition of sulphate content. Qiu et al. (2006) reported that excessively sulphate fucoidan showed four times higher in anticoagulant activity than fucoidan in protothrombin doubling time of normal human citrate plasma.

Sulphate group position on sugar residue is crucial for anticoagulant activity of fucoidan. This activity is related to sulphate $\mathrm{C}-2$ and disulphate $\mathrm{C}-2,3$. The disulphate 2,3 sugar residues are common structural properties in fucoidan as anticoagulant. Duarate et al. (2001) reported that the anticoagulant properties of fucoidan are determined largely by the sulphate fucose chain, particularly by fucosyl disulphate unit. Silva et al. (2005) reported that sulfate 3-O at C-3 of the 4- $\alpha$-L-fucose- 1 unit was responsible for the anticoagulant activity of fucoidan from Padina gymnospora.

An expected fucoidan is having a long and thrombin bonded conformation sugar chain structure, so it takes a large molecular weight to have anticoagulant activity. Fucoidan (MW 320,000) of Lessonia vadosa (Phaeophyta) showed significant by anticoagulant activity, whereas its radical depolimerized fraction (MW 32,000) showed weak anticoagulant activity. Even a slight decrease in molecular size of sulphate fucan reduces its effect significantly on the inactivation of thrombin by heparin cofactor II. Sulphate fucan with 45 units of repeating tetrasaccharide attach to heparin cofactor II but they can not connect efficiently the plasma inhibitor with thrombin. Therefore it is required for at least 100 or more repeating tetrasaccharide units in order to the effect to be occured. In thrombin inactivation process by linear sulphate linear induced by heparin cofactor II, casting mechanism is more dominating than the allosteric effect. Linear sulphate fucan requires longer chain than mamals glycosaminoglycan to obtain anticoagulant activity.

Low molecular weight of fucoidan (LMWF) extracted from Ascophyllum nodosum through acid hydrolysis has a repeating structure of $[1 \rightarrow 3)-\alpha-\mathrm{L}-\mathrm{Fuc}\left(2 \mathrm{SO}_{3}^{-}\right)$$(1 \rightarrow 4)-\alpha-L-F u c\left(2,3\right.$ diSO $\left._{3}^{-}\right)-(1]_{n}$ and molecular weight of $3090 \mathrm{Da}$ and also has in vitro anticoagulant activity. It means that the anticoagulant activity is not only based on molecular weight, but also determined by the branched structure. Sulphation level of LMWF has three sulphate for every disaccharide, the same as heparin main repeating unit [4)- $\alpha$-L-IdoA $\left(2 \mathrm{SO}_{3}{ }^{-}\right)$$(1 \rightarrow 4)-\alpha$-D-Glc- $\left.\left(\mathrm{NSO}_{3}^{-}, 6 \mathrm{SO}_{3}^{-}\right)-1 \rightarrow 3\right]_{n}$.

Several studies showed that sugar composition (fucose, galactose, etc.) of fucoidan is associated with anticoagulant activity. But it is presumably that it is not the sugar but sulphate which has the effect on anticoagulant activity. Pereira et al. (2002) demonstrated that sulphate 2,3 linked to $\alpha$-L-galactan, but not to $\alpha$-L-fucan is a potential thrombin inhibitor via antithrombin or heparin cofactor II media. Uronic acid was not required for anticoagulant activity, but it can increase the anticoagulant activity by increasing the flexibility of the sugar chain.

Clearly, many fucoidans could be prolong their APTT, but slightly delay their TT. This stated that the anticoagulant activity is mainly due to coagulant endogenesis approach which is restrained by fucoidan (Li et al., 2008; Zhao et al., 2005). However, fucoidan derived from fermented brown seaweed Sargassum fulvellum can inhibit intrinsic and extrinsic pathway of blood coagulation (Zheng et al., 2002).

Thrombin plays an important role in thrombosis, so thrombin inhibitor is the core of the antithrombotic drug research. Many studies showed that most of the anticoagulant activity of fucoidan is mediated via antithrombin inhibition by heparin cofactor II. Its activity also accelerates thrombin inhibition and Xa factor by antithrombin but at lower potential. However, Zoysa et al. (2008) reported that the anticoagulant properties of fucoidan from $F$. vesiculosus was determined by thrombin inhibition mediated via in vitro and in vivo plasma antithrombin-III trials, has a similar anticoagulant activity with heparin. 
Mourao (2004) summarized antithrombosis and anticoagulant activity of sulphate fucan. Sulphate fucan derived from algae and invertebrate had strong anticoagulant activity, mediated by antithrombin and/ or heparin cofactor II. This aspect was clarified by research on invertebrate derived polysaccharides. These results clearly established that the structure of linear and regulated sulphate $\alpha$-L-fucan and sulphate D L- $\alpha$-galactan showed anticoagulant activity, suggesting not only a function of charge density, but also on the composition pattern of sulphate and monosaccharide.

Melo et al. ( 2004) conducted a study on the mechanism of anticoagulant activity of sulphate galactan. Anticoagulant activity of sulphate polysaccharide was achieved mainly via cofactor plasma charge which is a natural inhibitor of coagulation protease. Their results showed the following: 1) structural interaction requirement between sulphate galactan with coagulation inhibitor and targeted protease was not just a consequence of the sulphate galactan charge density, 2) basic structure of this interaction was complex because it is usually involved a heterogeneous polysaccharide but it depend on the distribution of sulphate group and monosaccharide composition, 3) it was needed a longer chain of sulphate galactan than heparin to reach the anticoagulant activity, 4) it was possible that sulphate galactan structure was large, not small component such as heparin, however its interaction with antithrombin was the decisive factor, 5) sulphate galactan of molecular weight $15-45 \mathrm{kDa}$ binded antithrombin but it can not reach the plasma and thrombin inhibitors. This last effect required molecular size of $45 \mathrm{kDa}, 6$ ) sulphate galactan and heparin binded to a different binding site on antithrombin, 7) compared to heparin, sulphate galactan was less effective in promoting antithrombin activation via structural conformation. Overall, those observations suggested that different mechanisms dominated on antithrombin activation via structural conformation to ensure anticoagulant activity of sulphate galactan mediated by antithrombin. It was possible that sulphate galactan linked both with antithrombin and thrombin, and left protease in its inactive form. Antithrombin activation via structural conformation and covalent complex formation with thrombin seem less important in anticoagulant activity of sulphate galactan than that of heparin. Results showed that interaction paradigm between heparin and antithrombin can not be applied to other sulphate polysaccharides. Any type of polysaccharides can be form a specific complex with plasma inhibitors and targeted protease.

\section{Antioxidant Activity}

Several studies showed that fucoidan had significant in vitro antioxidant activity. Fucoidan is a natural antioxidant and has the potential to prevent diseases caused by free radicals. Fucoidan from brown seaweed $L$. japonica clearly can prevent the increase of lipid peroxides in the blood serum, liver and spleen of mice with diabetes. However, there was no inhibitory effect either on spontaneously lipid peroxidation homogenate or induced in vitro by Cys / FeSO4 (Cumashi et al., 2007). Fucoidan had strong scavenging effect on superoxide radicals, its effect on hydroxyl radical was weak and less effect on DPPH. This fucoidan effectively inhibited $\mathrm{H}_{2} \mathrm{O}_{2}$ induced hemolysis in mice erythrocytes and showed a significantly protective effect on lipid peroxidation in liver homogenate of mice induced by $\mathrm{FeSO} 4$-ascorbic acid combination (Qiu et al., 2006). Micheline et al., (2007) reported that fucoidan homofucan from $F$. vesiculosus and heterofucan from Padina gymnospora had an inhibition effect on the formation of hydroxyl and superoxide radicals. Fucan showed lower antioxidant activity than fucoidan.

The antioxidant activity of fucoidan is related to molecular weight and fucoidan sulphate content. Fucoidan fraction of $L$. japonica has a very good scavenging capacity on superoxide radicals and hipochloric acid, except for L-B sulphate fraction. In LDL oxidation system, L-A and L-B low molecular weight fraction showed a significant inhibitor effect on LDL oxidation induced by $\mathrm{Cu}^{2+}$, but F-A and F-B had a weak inhibitory effect in the system because of their large molecular weight. Both molecular weight and fucoidan sulphate content have a very important role on these effects on azo 2-2'-azobis (2-amidinopropan) dihydrochloride (AAPH) radical induced by LDL oxidation. Correlation between sulphate content and superoxide radical scavenging ability is positive, ratio of sulphate content and fucose is an effective indicator of antioxidant activity in the sample (Zhao et al., 2005).

\section{Anticomplementary Activity}

Complement system is a major component in immunity and primarily is involved in innate and humoral responses. The system also provides a link between innate immunity and adaptation responsed self-defense. Uncontrolled activities in the system resulted in harm to the host organism, such as those observed in ischemic and anaphylactic shock or xenograft rejection (Tissot \& Daniel, 2003). Algal fucoidan of Ascophyllum nodosum was first reported as a anticomplementer molecule by Blondin et al. (1996). In addition, other fucoidan of fucales ( $F$. evanescens) and other brown algae of Laminariale also reported to have complement inhibitor properties. Tissot \& Daniel (2003) summarized research on anticomplementer activity of fucoidan. 


\section{Anti-inflamation}

All fucoidan derived from 9 species of brown algae inhibited leucocytes mobilization using inflammatory model in mice, and both fucose and sulphate content as well as other structural properties of their polisaccharide chain did not exhibited evident effect of fucoidan in the model. Mekabu fucoidan can eliminate inflammation in lung (pulmonary) with response to down-regulated Th2-dominated, which may be useful for treating inflammation caused by allergies (Maruyamaa et al., 2005). Yang et al. (2006) investigated the effects of fucoidan on inducible nitric oxide synthase (iNOS) expression in a macrophage cell line, RAW264.7. Fucoidan in low concentration range $(10 \mu \mathrm{g} / \mathrm{ml})$ increased alkaline iNOS expression levels in stationary macrophage. Yang et al. (2006) discovered for the first time that fucoidan inhibited nitric oxide (NO) release in RAW264.7 cells stimulated with lipopolysaccharide (LPS). Inhibitory effect on activator protein 1 (AP-1) activated by fucoidan may be related to NO closing and anti-inflammatory effect.

\section{Gastric Protector}

Fucoidan from Cladosiphon okamuranus Tokida is a safe material and has potential as a gastric protector. It is available an antiulcer drug and adhesion inhibitor for Helicobacter pyroli containing fucoidan as active ingredient. The new drug is effective in treating and preventing gastritis and inhibiting adhesion of Helicobacter pyroli in the stomach (Shibata et al., 2000; Silva et al., 2005). Fucoidan from C. okamuranus showed cancer cell growth inhibition activity in the stomach but did not show any effects on normal cells. The sulphate content and molecular weight of the fucoidan were $9.8 \%(\mathrm{w} / \mathrm{w})$ and approximately 3.2 million, respectively (Tissot \& Daniel, 2003).

\section{Lowering Blood Lipid Level}

Fucoidan is among active agents similar to sialic acid and may increase negative charge of cell surface such as causing effect on the aggregation of cholesterol in blood, then lowering cholesterol level in serum. Fucoidan of $L$. japonica can actually lower total cholesterol, triglycerides, and LDL-C and raising HDL$\mathrm{C}$ in serum of mice suffering from hypercholesterolemia and of rat with hyperlipidemia, and efficiently prevented the formation of hipercholesterolemia via experiments in mice. The fucoidan also can actually lowered cholesterol and triglyceride levels in the serum of patients with hyperlipidemia, without the side effects that damage liver and kidneys (Wang et al., 2008). Sulphate fucan of low molecular weight (molecular weight approximately of $8000 \mathrm{Da}$ ) from L. japonica clearly lowered blood lipid in rats with hyperlipidemia. Oligosaccharide fucoidans showed good antihypertensive effect in renovascular hypertensive rats and one possible mechanism was that fucoidan might inhibit the production of angiotensin II plasma (Zoysa et al., 2008).

\section{CONCLUSION}

Fucoidan extracted from brown seaweed has a complex and heterogeneous structure, that's why the structure has not been clearly described until now. However, fucoidan has interesting biological activity so that many researches are conducted to investigate their structure and bioactivity every year. Since bioactivity tests is conducted using crude fucoidan, it is not easy to determine the relationship between their structure and activity. But, at least, we learned that these bioactivities not only depend on their high charge density, but also their structure. The upcoming research on the conformational structure of fucan should focus on deeper understanding on the biological properties of fucoidan. Brown algae are abundant throughout the world and some species (e.g. $\mathrm{H}$. fusiforme, L. japonica) has been cultivated on a large scale. Currently most of the brown algae are consumed as food or additives in food, while some of them have developed into new drugs and functional foods. Through chemical modification, such as sulphation process in certain position and methylation, some activities of fucoidan increase significantly. By focusing research on the structure of fucoidan and investigate the relationship between its activity and structure can provide a basic theory in resource development and utilization of brown algae.

\section{REFFERENCES}

Anno, K., Terahata, H., and Hayashi, Y. 1966. Isolation and purification of fucoidan from brown seaweed Pelvetia wrightii. Agri. Biol. Chem. 30: 495-499.

Bilan, M.I., Grachev, A.A., Ustuzhanina, N.E., Shashkov, A.S., Nifantiev, N.E., and Usov, A.I. 2004. A highly regular fraction of a fucoidan from the brown seaweed Fucus distichus L. Carbohydr. Res. 339: 511-517.

Bilan, M.I., Grachev, A.A., Shashkov, A.S., Nifantiev, N.E., and Usov, A.I. 2006. Structure of a fucoidan from the brown seaweed Fucus serratus L. Carbohydr. Res. 341: 238-245.

Black, W.A.P., Dewar, E.T., and Woodward, F.N. 1952. Manufacture of algal chemicals. IV. -Laboratory-scale isolation of fucoidan from brown marine algae. $J$. Sci. Food Agric. 3: 122-129.

Blondin, C., Chaubet F., Nardela, A., Singuin, C., and Jozefonvicz, J. 1996. Relationships between 
chemical characteristics and anticomplementary activity of fucans. Biomaterials. 17: 597-603.

Conchie, J. and Percival, E.G.V. 1950. Fucoidan part II. The hydrolysis of a methylated fucoidin prepared from Fucus vesiculosus. J. Chem. Soc. 827-833.

Cumashi, A., Ushakova, N.A., Preobrazhenskaya, M.E., D'Incecco, A., Piccoli, A., Totani, L., Tinari, N., Morozevich, G.E., Berman, A.E., Bilan, M.I.,Usov, A.I., Nadezhda E., Grachev, A.A., Sanderson, C.J., Kelly, M., Rabinovich, G.A., and lacobelli, S. 2007. A comparative study of the anti-inflammatory, anticoagulant, antiangiogenic, and antiadhesive activities of nine different fucoidans from brown seaweeds. Glycobiology. 17: 541-552.

Duarate, M., Cardoso, M., and Noseda, M. 2001. Structural studies on fucoidans from the brown seaweed Sargassum stenophyllum. Carbohydr. Res. 333: 281293.

Janet Helen Fitton. 2011. Therapies from Fucoidan; Multifunctional Marine Polymers., Mar. Drugs. 9(10): 1731-1760.

Kim, W.J., Kim, S.M., Kim, H.G., Oh, H.R., Lee, K.B., Lee, Y.K., Park, Y.P. (2007). Purification and Anticoagulant Activity of a Fucoidan from Korean Undaria pinnatifida Sporophyll. Algae. 22: 247-252.

Li, B., Lu, F., Wei, X., and Zhao, R. 2008. Fucoidan: Structure and Bioactivity, Molecules. 13: 1671-1695.

Li, B., Rui, X.Z., and Xin, J.W. 2008. Anticoagulant activity of fucoidan from Hizikia fusiforme. Agro Food Ind. Hitech. 19: 22-24.

Maruyamaa, H., Tamauchib, H., Hashimotoc, M., and Nakano, T. 2005. Suppression of Th2 immune responses by Mekabu fucoidan from Undaria pinnatifida Sporophylls. Int. Arch. Allergy Immunol. 137: 289-294.

Melo, F.R., Pereira, M.S., Foguel, D., and Mourao, P.A.S. 2004. Antithrombin-mediated Anticoagulant Activity of Sulfated Polysaccharides. J. Biol. Chem. 279: 2082420835.

Micheline, R.S., Cybelle, M., Celina, G.D., Fernando, F.S., Hugo, O.R., and Edda, L. 2007. Antioxidant activities of sulfated polysaccharides from brown and red seaweeds. J. Appl. Phycol. 19: 153-160.

Minh Bui, L., Ngo Quoc, B., Nguyen D., Pham Duc, T., and Tran T. 2005. Studies on fucoidan and its production from vietnamese brown seaweeds. AJSTD. 22(4): 371-380.

Mourao, P.A.S. 2004. Use of sulfated fucans as anticoagulant and antithrombotic agents: future perspectives. Curr. Pharmaceut. Des. 10: 967-981.
Nishino, T. and Nagumo, T. 1992. Anticoagulant and antithrombin activities of oversulfated fucans. Carbohydr. Res. 229: 355-362.

Nishino, T., Nagumo, T., and Kiyohara, H. 1991. Structure characterization of a new anticoagulant fucan sulfate from the brown seaweed Ecklonia kurome. Carbohydr. Res. 211: 77-90.

O'Neill, A.N. 1954. Degradative studies on fucoidan. J. Amer. Chem. Soc. 76: 5074-5076.

Patankar, M. S., Oehninger, S., and Barnett, T. 1993. A revised structure for fucoidan may explain some of its biological activities. J. Biol. Chem. 268: 2177021776.

Pereira, M.S., Vilela-Silva, A. E. S., Valente, A., and Mourao, P. A. S. 2002. a 2-sulfated, 3-linked t-Lgalactan is an anticoagulant polysaccharide. Carbohydr. Res. 337: 2231-2238.

Qiu, X. D., Amarasekara, A., and Doctor, V. 2006. Effect of oversulfateion on the chemical and biological properties of fucoidan. Carbohydrate Polymers. 63: 224-228.

Shibata, H., Kimura-Takagi, I., Nagaoka, M., Hashimoto, S., Aiyama, R., Iha, M., Ueyama, S., and Yokokura, T. 2000. Properties of fucoidan from Cladosiphon okamuranus tokida in gastric mucosal protection. BioFactors. 11: 235-245.

Silva, T. M. A., Alves, L. G., Queiroz, K. C. S., Santos, M. G. L., Marques, C. T., Chavante, S. F., Rocha, H. A. O., and Leite, E. L. 2005. Partial characterization and anticoagulant activity of a heterofucan from the brown seaweed Padina gymnospora. Braz. J. Med. Biol. Res. 38: 523-533.

Sinurat, E., Rosmawaty, P., dan Saepudin, E. 2011. Ekstraksi dan Uji Aktivitas Fukoidan dari Rumput Laut Coklat (Sargassum crassifolium) sebagai Antikoagulant. Jurnal Pascapanen dan Bioteknologi Kelautan dan Perikanan. 6(2): 131-138.

Tissot, B. and Daniel, R. 2003. Biological properties of sulfated fucans: the potent inhibiting activity of algal fucoidan against the human complement system. Glycobiology. 13: 29G-30G.

Wang, J., Zhang, Q., Zhang, Z., and Li, Z. 2008. Antioxidant activity of sulfated polysaccharide fractions extracted from Laminaria japonica. Int. J. Biol. Macromol. 42: 127-132.

Yang, J.W., Se, Y.Y., Soo, J.O., Sang, K.K., and Keon, W.K. 2006. Bifunctional effects of fucoidan on the expression of inducible nitric oxide synthase. Biochem. Biophys. Res. 346: 345-350.

Zhao, X., Xue, C.H., Cai, Y.P., Wang, D.F., and Fang, Y. 2005. The study of antioxidant activities of fucoidan from Laminaria japonica. High Tech. Lett. 11: 91-94.

Zheng, J., Wang, Y., and Qian, J.J. 2002. Isolation, purification and the anticoagulant activities of fucoidan. J. Mol. Sci. 18: 109-112.

Zoysa, M., Nikapitiya, C., Jeon, Y.J., Jee, Y., and Lee, J. 2008. Anticoagulant activity of sulfated polysaccharide isolated from fermented brown seaweed Sargassum fulvellum. J. Appl. Phycol. 20: 67-74. 